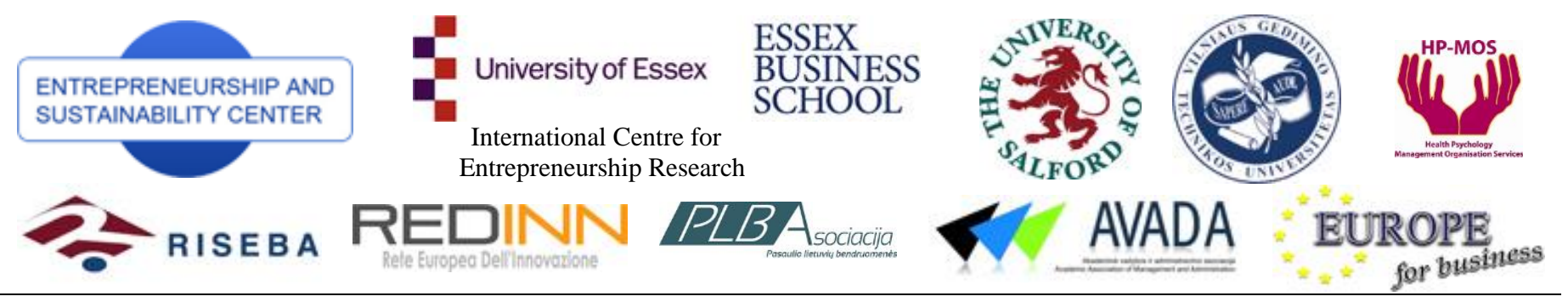

ENTREPRENEURSHIP AND SUSTAINABILITY ISSUES

ISSN 2345-0282 (online) http://jssidoi.org/jesi/

\title{
ENERGY EFFICIENCY FACETS: INNOVATIVE DISTRICT COOLING SYSTEMS ${ }^{1}$
}

\author{
Francesco Passerini ${ }^{1}$, Raymond Sterling ${ }^{2}$, Markus Keane ${ }^{2}$, Krzysztof Klobut ${ }^{3}$, Andrea Costa ${ }^{1}$ \\ ${ }^{I}$ R2M solution s.r.l., Via Fratelli Cuzio 42 \\ 27100 Pavia, Italy \\ ${ }^{2}$ National University OF Ireland Galway, University road \\ Galway, Ireland \\ ${ }^{3}$ Technical Research Centre of Finland, Vuorimiehentie 3 \\ 02150 Espoo, Finland \\ E-mail: ${ }^{1}$ francesco.passerini@r2msolution.com
}

Received 15 September 2016; accepted 20 November 2016

\begin{abstract}
Cooling demand in buildings is globally increasing, therefore developing more efficient cooling systems is important for the sustainability of European cities. Directive 2012/27/EU of the European Parliament and of the council on energy efficiency states: "Member States should carry out a comprehensive assessment of the potential for high-efficiency cogeneration and district heating and cooling". The EU project INDIGO is investigating this issue considering also the economic efficiency and the use of renewable energy sources.

In a district cooling system different kinds of cooling production can be combined. E.g., the use of absorption chillers with waste heat or through the solar cooling or the use of free cooling (generally the heat is rejected to seas, lakes, rivers or waterways) offer the possibility of a more sustainable way of cooling. Controlling those systems in an efficient way is a complex problem (consider that the cooling demand is much more difficult to predict than the heat demand, particularly the peaks, and sources such as the solar energy and the waste heat are not predetermined by the designers).

The main results of INDIGO will be the development of:

- predictive controllers (responsible for obtaining the HVAC systems set-points and based on component dynamic thermos-fluid models, some of them also including embedded self-learning algorithms);
\end{abstract}

${ }^{1}$ INDIGO has received funding from European Union's Horizon 2020 research and innovation programme under grant agreement $n^{\circ} 696098$.

The article reflects the views only of the authors, and the Commission cannot be held responsible for any use which may be made of the information contained therein. The information in this document is provided as is and no guarantee or warranty is given that the information is fit for any particular purpose. The user thereof uses the information at its sole risk and liability 
- system management algorithms (focused on energy efficiency maximization or energy cost minimization);

- an open-source planning tool (based on design and performance parameters as well as simulation and optimisation results; LCA framework will be used as a method for both economic feasibility and climate impact assessment).

To validate the results, the consortium is analysing case studies, both through energy modelling and through on-site observations and measurements. The present paper focuses mainly on the development of dynamic energy models and on their use in the context of the project.

Keywords: energy efficiency, predictive controllers, new system management algorithms, new planning tool, more efficient district cooling systems, energy models

Reference to this paper should be made as follows: Passerini, F., Sterling, R., Keane, M., Klobut, K., Costa, A. 2017. Energy efficiency facets: innovative district cooling systems, Entrepreneurship and Sustainability Issues, Entrepreneurship and Sustainability Issues 4(3): 310-318 http://dx.doi.org/10.9770/jesi.2017.4.3S(6)

JEL Classifications: C63, C88

Additional Disciplines Mechanical Engineering

\section{Introduction}

Energy efficiency issues are widely discussed in scientific literature (e.g. Vosylius et al. 2013; Lapinskienè et al. 2014; Tvaronavičienè et al. 2015; Tvaronavičienė 2016; Strielkowski et al. 2016). Directive 2012/27/EU of the European Parliament and of the council on energy efficiency states: "Member States should carry out a comprehensive assessment of the potential for high-efficiency cogeneration and district heating and cooling". INDIGO is a project that is funded by the European Union's Horizon 2020 research and innovation program and is investigating the improvement of the district cooling systems. It started in March 2016 and is going to last 42 months. The importance of the development of efficient cooling systems is clear if we consider that:

- according to different prognosis the cooling demand in the EU27 countries will increase significantly in the next decades (RESCUE Project. 2013);

- due to the cooling demand, often in city centres and in commercial areas the electricity peak loads appear during the summer season (Frederiksen, S.; Werner, S. 2013).

The management of cooling systems shall consider that providing cooling efficiently is more difficult than providing heating.

The cooling demand is more difficult to predict than the heat demand (Frederiksen, S.; Werner, S. 2013) because it depends on different factors that can change quickly, e.g. on solar radiation, on internal heat gains, and on the "urban heat island" effect. Since the cooled spaces are generally more commercial than residential and the solar radiation has a large influence on the cooling loads, the daily load variation is rather large for district cooling systems. Moreover, temperature differences between the supply water temperature and the return water temperature for district cooling (DC) networks are generally around $8^{\circ} \mathrm{C}$, while in district heating (DH) networks the difference is usually greater than $40^{\circ} \mathrm{C}$. For district cooling systems this causes an increase in the cost of the piping system and of the energy requirements for pumping.

In a district cooling system different kinds of cooling production can be combined. E.g., the use of free cooling (generally the heat is rejected to seas, lakes, rivers or waterways) or the use of absorption chillers with waste heat or solar heat offer the possibility of a more sustainable way of cooling. Controlling those systems in an efficient way is a complex problem (sources such as actual solar energy are not predetermined).

The goal of INDIGO is to provide tools that can help the designers and the energy managers that deal with district cooling. The project deals with all the parts of the system: generation, distribution, storage, and demand. In order to facilitate the proper control of complex systems, one of the main results of the project will be the development 
of predictive controllers. They will be responsible for obtaining the HVAC system set-points and will be based on component dynamic thermal-fluid models, some of them also including embedded self-learning algorithms.

The control system will consider an innovative system management strategy which will take in account both the energy savings and the costs.

To assist the designers' work, INDIGO is going to develop an open-source planning tool. It will be based on design and performance parameters as well as simulation and optimisation results. The LCA framework will be used as a method for both economic feasibility and climate impact assessment. A library with thermo-fluid dynamic models of DC System components will provide the designers detailed information about the systems.

Next sections of this paper focus on the project demonstration site (section 2), energy modelling approach (section 3) and conclusions.

\section{Project implementation in a real pilot district}

The results of INDIGO are going to be validated in a real District Heating and Cooling (DHC) installation, i.e. in the Basurto Hospital, in Bilbao. The hospital is divided in about 20 buildings and belongs to Osakidetza, the public health service of the Basque Country. Heating and cooling demand of the hospital is satisfied thanks to a DHC installation connected to a trigeneration plant (electricity, heat and cold). The DHC system was installed in the hospital site in 2003 by GIROA, and extended in 2011. GIROA-Veolia currently owns and operates the system and also the HVAC systems in the buildings. Nowadays the trigeneration plant consists of 2 natural gas internal combustion engines of 2MWe (each), some natural gas backup boilers, and 2 absorption chillers plus 4 conventional chillers for cooling purposes.

The cooling demand is very stochastic since it depends on the number of programmed surgeries (operating room usage), rooms occupancy level, as well as on the weather data.

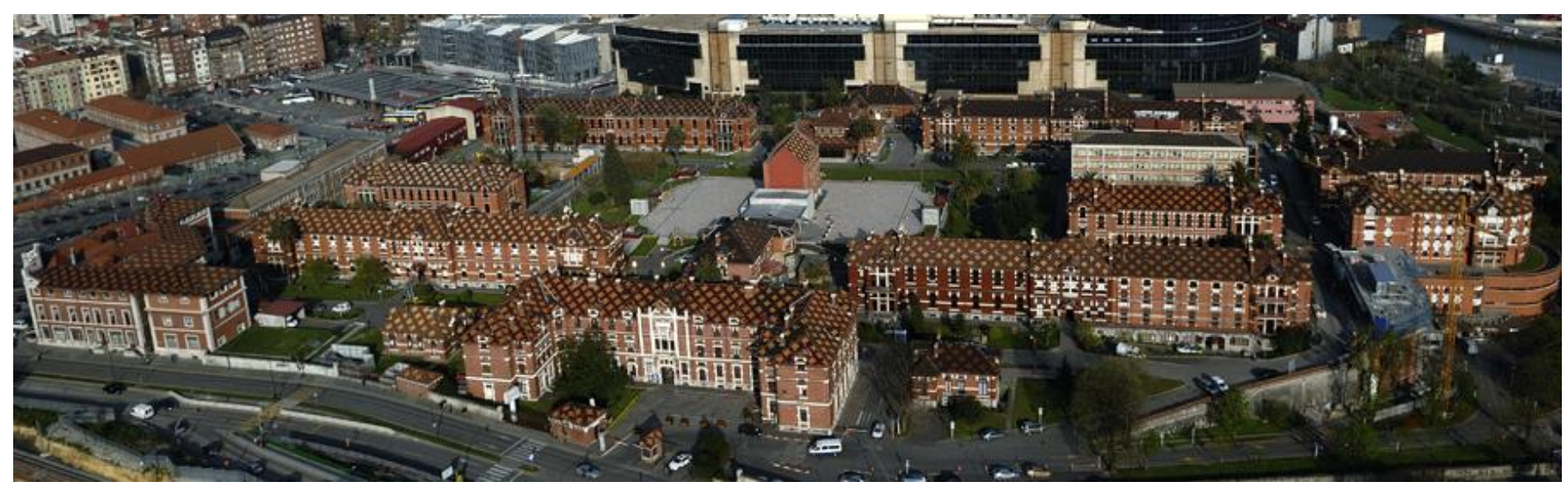

Fig.1. A case study: the Basurto hospital in Bilbao

Source: www.irekia.euskadi.eus

In the Basurto hospital the actual impact of the predictive controllers and of the innovative management strategy is going to be tested. As a first phase, the test will be through simulations. As a second phase, the results of INDIGO will be implemented and measured onsite. 


\section{Energy modelling approach}

Different partners of the consortium are developing different parts of a model that regards the buildings and all the components of the DC system. The different parts are:

1. generation systems;

2. distribution and storage systems;

3. HVAC systems inside the buildings;

4. thermal behaviour of the buildings, internal loads, and building use.

The first three parts are being developed in Modelica, the fourth one in EnergyPlus. They are going to be integrated through the Functional Mock-up Unit (FMU) for co-simulation (Nouidi, T.S. 2014). The coordination among the energy modellers of the different parts is anyway fundamental in order to avoid problems at the interfaces between the different parts. E.g. the thermal zones are created by the energy modeller who is responsible for the building but they will affect also the model of the HVAC system inside the building. Other interfaces are between the different parts of the HVAC system (generation, distribution, storage, heat exchange, AHUs...).

The integration of different tools can permit the exploitation of their different capabilities. EnergyPlus is a whole building energy simulation program. It is a free, open-source, and cross-platform. Its purpose is the evaluation of the energy consumption and comfort conditions relative to the building. In EnergyPlus many models relative to the building envelope and to the HVAC systems are available and already tested. Modelica is a free modelling language. It is component-oriented and it is more flexible than EnergyPlus. It can exchange data also with Building Management Systems (BMSs).

The energy modellers are collecting the data that are needed for their work. The first buildings of the hospital were erected during the first decade of the 20th century while the newest buildings were built about ten years ago. Since the situation is very variegated (from the point of view of the construction techniques and of the available data), the data collection is based on many sources: datasheets, design information (for the newest buildings), drawings, monitored data, equipment tags, on-site measurements, contacts with the facility manager and with the occupants. Since a BMS is present, some monitored data are stored and available through that system.

A monitoring plan for the envelope properties was developed and is going on. Since the project regards the cooling systems, a monitoring campaign is carried out during the summer season. Another campaign is going to be carried out in winter, which is the most appropriate season for some tests (e.g. for the detection of thermal bridges with the thermographic camera and for the measurement of the thermal transmittance of the envelope an important temperature difference -at least $10^{\circ} \mathrm{C}$ - between the internal environment and the external environment is necessary).

The thermal transmittance and the thermal conductance of the walls and of the roofs is going to be evaluated according to the technical standard ISO 9869-1:2014. The thermal flow, the outdoor and the indoor air temperatures and the surface temperatures are measured and the data, which are stored by a data logger, are going to be elaborated according to the standard. For the summer season the measured data can help understand the dynamic behaviour of the envelope. The external surface temperature and the heat flow rates that are obtained as result from EnergyPlus are going to be compared with measured data. Both the hourly trend and the total heat flow in a defined time slice (in some days) are going to be considered in the comparison. Since in the model of EnergyPlus parameters such as the solar absorbance of the external surface, its thermal emittance, the thermal properties of the layers that compose the wall (thermal conductivity, density, specific heat) influence the wall temperature and the heat flow rates, the monitored data will help in the definition of those parameters in the model. 
The International Journal

ENTREPRENEURSHIP AND SUSTAINABILITY ISSUES

ISSN 2345-0282 (online) http://jssidoi.org/jesi/

2017 Volume 4 Number 3 (March)

Since the thermographic camera is used for detecting thermal irregularities in the building envelope, the best positions of the heat flow meter have been evaluated on the basis of the observations made with the thermographic camera. The windows have generally a higher transmittance than opaque parts, they have much lower thermal inertia, and they are the main entrance for the solar energy. Because of these reasons, the properties of the windows are very important for the thermal behaviour of the buildings, particularly during the summer season. A pyranometer measures the solar radiation flux density $\left(\mathrm{W} / \mathrm{m}^{2}\right)$ and is used for measuring the solar irradiance on a planar surface. If the solar irradiance is measured on the outside surface of a window and then on the internal surface the solar transmission factor can be estimated.

The buildings that are part of the Basurto Hospital have pitched roofs. The most external layer is made by shingles, under which there is an air cavity. If the air cavity is ventilated with outdoor air, the ventilation can remove part of the entering heat, which is mainly due to solar radiation. In order to evaluate the air velocity, a hot wire anemometer is going to be used. In order to evaluate the air tightness of the building, an innovative test method is going to be applied in collaboration with the University of Nottingham, which is among the developers of the system. The system is called "Pulse" and is considered an alternative to the blower door test (Cooper, E. et al. 2015). The air leakages, particularly those ones at the perimeter of the windows, are going to be examined also through the use of the thermographic camera and of the hot wire anemometer.

As for the HVAC systems inside the buildings, component models for the air handlers (heating coils, cooling coils, humidifiers, etc.) in Basurto site will be developed in Modelica based on previously existing models such as those of the Modelica Buildings Library (Wetter, $\mathrm{M}$ et al. 2014). The air handlers will be built as a combination of component models matching the actual configuration of each AHU following the real physical interconnection in the plant. Given that the main focus of INDIGO is on cooling systems, the components directly linked to the district cooling systems (cooling coils and radiant cooling) will be modelled in higher details while any other component (e.g. heating coil, humidifiers, heat recovery) will be simplified in order to lower model complexity and decrease simulation times.

A common set of the physical parameters has been established for every component model: specific heat capacities of water and air, atmospheric pressure and the saturation efficiency. The element-specific parameters are commonly provided by the manufactures. Table 1 shows the manufacturer data used for each component (Table 1). 
Table 1. Parameters provided by the manufacturer

\begin{tabular}{|c|c|}
\hline COMPONENT & PARAMETER \\
\hline Mixing Box & No data required \\
\hline Heating Coil & Nominal air input temperature \\
& Nominal air output temperature \\
& Nominal air mass flow rate \\
& Nominal water input temperature \\
& Nominal water output temperature \\
& Nominal water mass flow rate \\
\hline Cooling Coil/ & Nominal air input temperature \\
Chilled Beams & Nominal air input relative humidity \\
& Nominal air output temperature \\
& Nominal air output relative humidity \\
& Nominal air mass flow rate \\
& Nominal water input temperature \\
& Nominal water output temperature \\
& Nominal water mass flow rate \\
\hline Humidifier & Maximum steam mass flow rate \\
& Steam temperature \\
\hline Fans & Nominal air flow rate \\
& Nominal power \\
& Fan curves \\
\hline
\end{tabular}

In order to obtain data required to validate the models in the environment of the Basurto site, a monitoring plan has been developed also for the HVAC systems. That monitoring plan requires the measurement of air temperature and relative humidity before and after the cooling element and also the air flow rate in order to determine the amount of energy delivered to the air. Ideally such data is readily available from the BMS. Also, in order to understand the relationship between control signal produced by the BMS and the actual actuator (e.g. valve) steady state data at various operation points (e.g. various valve openings) needs to be recorded.

All models developed will be independently validated using data acquired at test-site: models will be simulated and the results compared to acquired data. The validation will be carried out utilising acceptance testing criteria required by international standards such as ASHRAE Guideline 14-2002 and the international performance measurement and verification protocol (IPMVP).

After the models will be validated with measured data, they can be considered a reference point for the development of the innovative controllers and of the management strategy and the new models that are being developed in Modelica will be part of a District cooling open-source library (DCOL).

\section{Conclusions}

The research project INDIGO, which is funded by the EU's Horizon 2020 research and innovation program, is developing solutions for the improvement of the district cooling systems.

In the context of that project energy modelling is an important activity. The detailed energy models that are being developed consider all the relevant parts of the district cooling system and of the demand side (the building, which needs the control of the indoor air temperature and, in some cases, of the indoor humidity ratio). The development of the model is a complex process that involves different phases: identification of the required data, research of the required data, monitoring, validation of the model. 
In the development of the project the energy models are going to help in the development and in the evaluation of a predictive control system, of innovative management strategies, and of a new planning tool. The results of the research project could improve the design and the management of district cooling systems, in terms of efficiency, economic convenience, and environmental impact.

\section{References}

Advancements in Air Tightness Testing - The Low Pressure Pulse. Available on the Internet: <www.pulseairtest.com>

ASHRAE Guideline 14:2002 Measurement of Energy and Demand Savings

Cooper, E. et al. 2015. Field trialling of a new airtightness tester in a range of UK homes. The 36th AIVC Conference "Effective ventilation in high performance buildings", Madrid, Spain. Available on the Internet: http://www.aivc.org/sites/default/files/98_0.pdf

del Hoyo, I.; Herrero, S.; López, S.; Rämä, M.; Klobut, K. 2016 Development and validation of selected models for fast modelling the thermal energy transport in district networks. 11th Conference on Sustainable Development of Energy, Water and Environment Systems, SDEWES 2016, Lisbon, Portugal

Frederiksen, S.; Werner, S. 2013. District heating and cooling. Lund: Studentlitteratur AB

International Performance Measurement and Verification Protocol, Volume I, EVO 10000.1:2012 Concepts and Options for Determining Energy and Water Savings

ISO 9869-1:2014 Thermal insulation - Building elements - In-situ measurement of thermal resistance and thermal transmittance - Heat flow meter method

Lapinskienė G.; Tvaronavičienè M.; Vaitkus 2014. The emissions of greenhouse gases and economic growth - the evidence of the presence of the Environmental Kuznets curve in the European Union countries, Technological and Economic Development of Economy Vol. 20, Iss. 1: p.65-78 http://dx.doi.org/10.3846/20294913.2014.881434

Lopez, S., del Hoyo, I. 2014 Proposal for standardization of Heat Transfer Modelling in NewThermal Library. 10th International Modelica Conference, Lund, Sweden. Available the Internet:https://modelica.org/events/modelica2014/proceedings/html/submissions/ECP140961189_LopezperezDelhoyoarce.pdf

Nouidui, T.S.; Wetter, M.; Zuo, W. 2014. Functional mock-up unit for co-simulation import in EnergyPlus, Journal of Building Performance Simulation, 7(3): 192-202. DOI: http://dx.doi.org/10.1080/19401493.2013.808265

RESCUE Project. 2013. WORK PACKAGE 2 - EU DISTRICT COOLING MARKET AND TRENDS. Available on the Internet: < http://www.rescue-project.eu/fileadmin/user_files/WP2_Reports/RESCUE_WP_2.3_EU_COOLING_MARKET.pdf>

Strielkowski, W.; Lisin, E.; Tvaronavičienè, M. 2016. Towards energy security: sustainable development of electrical energy storage, Journal of Security and Sustainability Issues 6(2): 43-52. http://dx.doi.org/10.9770/jssi.2016.6.2(4) 
The International Journal

ENTREPRENEURSHIP AND SUSTAINABILITY ISSUES

ISSN 2345-0282 (online) http://jssidoi.org/jesi/

2017 Volume 4 Number 3 (March)

Tvaronavičienė, M. 2016. Entrepreneurship and energy consumption patterns: case of households in selected countries, Entrepreneurship and Sustainability Issues 4(1): 74-82. http://dx.doi.org/10.9770/jesi.2016.4.1(7)

Tvaronavičienė, M.; Mačiulis, A.; Lankauskienė, T.; Raudeliūnienė, J.; Dzemyda, I. 2015. Energy security and sustainable competitiveness of industry development // Economic research = Ekonomska istraživanja. Pula: Taylor \& Francis 28(1): 502-516 Research-Ekonomska Istraživanja, 28:1, 502-515 http://dx.doi.org/10.1080/1331677X.2015.1082435

Vosylius, E.; Rakutis, V.; Tvaronavičiené, M. 2013. Economic growth, sustainable development and energy security interrelation, Journal of Security and Sustainability Issues 2(3): 5-14, http://dx.doi.org/10.9770/jssi.2013.2.3(1)

Wetter, M.; Wangda, Z.; Nouidui, T.S.; Pang, X. 2014. Modelica Buildings library, Journal of Building Performance Simulation, 7(4): p.253-270. DOI: http://dx.doi.org/10.1080/19401493.2013.765506

\section{Aknowledgements}

INDIGO has received funding from European Union's Horizon 2020 research and innovation programme under grant agreement $n^{\circ}$ 696098.

Osakidetza is the public health service of the Basque countries and it is the owner of the Basurto hospital, where Veolia-Giroa (partner of the project consortium) manages the DC systems. Osakidetza and Veolia-Giroa are permitting the use of the Basurto hospital as a pilot case.

The article reflects the views only of the authors, and the Commission cannot be held responsible for any use which may be made of the information contained therein. The information in this document is provided as is and no guarantee or warranty is given that the information is fit for any particular purpose. The user thereof uses the information at its sole risk and liability

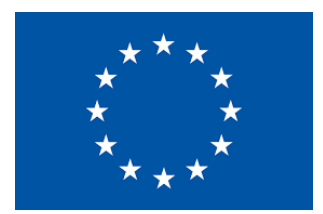

\section{Authors}

Francesco PASSERINI holds a Doctoral degree from the University of Trento in Environmental Engineering with specialization in sustainable buildings. His research work focused on passive solar systems, the calculation of the building energy performance and the refurbishment of blocks of flats. He has dealt with sustainable buildings and energy modeling, both at the academic level and in the private sector. He is member of AICARR (Italian Association for HVAC systems) and of IBPSA-Italy (the Italian regional affiliate of the International Building Performance Simulation Association).

ORCID ID: 0000-0001-5147-1425

Raymond STERLING has a double degree in Electrical Engineering (2009) and Systems Engineering (2008) from the Central University of Venezuela and University of Rome "La Sapienza" respectively. In 2010, he successfully completed a postgraduate Masters of Science in Intelligent Systems in the University of Salamanca, with a dissertation on Neural Network Control of HVAC Systems. Between October 


\section{The International Journal}

ENTREPRENEURSHIP AND SUSTAINABILITY ISSUES

ISSN 2345-0282 (online) http://jssidoi.org/jesi/ 2017 Volume 4 Number 3 (March)

2010 and February 2011 he participated in the traineeship program of the European Commission, providing technical and logistic support to the "New Forms of Production" unit of the Industrial Technologies Directorate within the Research and Innovation Directorate General. He was awarded with a PhD in Civil Engineering for his work under the title: Self-Aware Buildings: An evaluation framework and implementation technologies for improving building operations, supervised by Dr. Marcus M. Keane. Raymond is currently a postdoctoral researcher in the College of Engineering and Informatics at NUI Galway.

ORCID ID: 0000-0001-9545-7908

Markus KEANE graduated from National University of Ireland Galway (NUIG) in 1988 with a first class honours degree in mechanical engineering. He completed his PhD at NUIG in 1994 focusing on the development of Computer Aided Learning Environments to support building energy simulation under the EU sponsored SAFE programme and the University of California Scholarship. He was awarded the John Murphy postdoctoral Research fellowship by UCC in 1992 with the remit of developing an undergraduate Environmental Building Services stream within the department of Civil \& Environmental Engineering and the development of a research programme in informatics in building services. He was appointed college lecturer in the department of Civil \& Environmental engineering in 1993 and promoted to Senior Lecturer in 2006. Dr. Keane established the Informatics Research Unit in Sustainable Engineering (IRUSE) in 2000 at the commencement of the HEA-PRTL2 funded Environmental Research Institute (ERI) programme. Dr. Keane has published over 25 peer reviewed papers relating to the "Green Building" project in the last seven years and obtained over 1.5Million in research funding in that same period. Dr. Keane has established strong research links with renowned universities in his field that include the University of California at Berkeley and Georgia Institute of Technology. Dr. Keane has research projects supported by funding agencies that include HEA PRTL programme, Sustainable Energy Ireland (SEI), Embark Initiative and Enterprise Ireland and Science Foundation Ireland (SFI). ORCID ID: 0000-0002-6785-3484

Krzysztof KLOBUT, senior scientist, has 30 years of scientific experience in the field of heating systems, energy consumption in buildings, RES, district heating and residential applications of fuel cells. He was involved in a number of projects co-funded by EC FP5\&6 (JOULE-PSI, EDIFICIO, SSHORT, BOILERNOISE), SAVE-programme (Boilsim, Indirect, Savelec) and IEA coordinated (ECBCS, Annexes 37 and 42). Recently he was involved in the following recently completed EC-funded projects: IDEAL EPBD (IEE), IntUBE (FP7) and AmI_MoSES (FP7). Currently he contributes to the following ongoing EU-projects: Ambassador, Design4Energy and Indigo. Mr. Klobut has authored or co-authored over 80 scientific publications.

ORCID ID: 0000-0002-5892-7066

Andrea COSTA is originally a graduate from the Politecnico di Milano. He pursued and was awarded a PhD in Civil Engineering from the National University of Ireland Galway (NUIG) with a PhD topic of providing support to the energy manager in improving the building operation strategy with considerations on building energy use and occupant comfort throughout the building lifecycle.

He is expert in building simulation with experience on an array of building energy simulation software and ISO 50001 certification tools. After his PhD, he was awarded an industrially supported Postdoctoral Fellow co-funded by IRCSET (Irish Research Council for Science Engineering and Technology) as part of the Enterprise Ireland Partnership Scheme and D'Appolonia Spa in Italy. Andrea Costa brings with him a balance of field and research experience including FP7 projects for energy efficiency with targeted focus for office buildings, airports, sport facilities, and schools.

ORCID ID: 0000-0001-7849-0052

Copyright (C) 2016 by author(s) and VsI Entrepreneurship and Sustainability Center This work is licensed under the Creative Commons Attribution International License (CC BY). http://creativecommons.org/licenses/by/4.0/ (c) (i) Open Access 